\title{
Effects of Iron Enrichment of Adzuki Bean (Vigna angularis) Sprouts on Elemental Translocation, Concentrations of Proteins, Distribution of Fe-Metalloproteins, and Fe Bioaccessibility
}

\author{
Aline P. de Oliveira and Juliana Naozuka* \\ Universidade Federal de São Paulo, Rua Prof. Artur Riedel, 275, 09972-270 Diadema-SP, Brazil \\ Iron $(\mathrm{Fe})$ is an essential element for human nutrition, and its deficiency or low hemoglobin \\ levels are a global health issue. Strategies aimed at increasing the amounts of essential elementals \\ in agricultural products, as sprouts of adzuki bean (Vigna angularis), can be a way to minimize \\ deficiencies, mainly in the populations of developing countries. Therefore, in this work was \\ evaluated: production of Fe-enriched adzuki bean sprouts; Fe accumulation and translocation \\ in plants in different culture media enriched with different Fe masses $(500,1000,2000$, and \\ $3000 \mu \mathrm{g}$ ); and effects of the enrichment by means of $3000 \mu \mathrm{g} \mathrm{Fe}$ \\ acid (Fe $\mathrm{FI}^{\mathrm{II}}$-EDTA): on the distribution of $\mathrm{Ca}, \mathrm{Cu}, \mathrm{Fe}, \mathrm{K}, \mathrm{P}, \mathrm{Mg}, \mathrm{S}$, and $\mathrm{Zn}$ in different parts of the \\ plant; on protein concentrations (albumins, globulins, prolamins, and glutelins) and their association \\ with $\mathrm{Fe}$ in edible parts of the plant (stems); and on Fe bioaccessibility in the edible part of the \\ plant (stems). The enrichment via Fe ${ }^{\mathrm{III}}$-EDTA favored the translocation and increased Fe content of \\ sprouts (75\%), besides promoting interactions of Fe with albumins (141\%), globulins (180\%), and \\ glutelins (93\%). In the bioaccessibility assays, Fe was $83 \%$ bioaccessible in Fe-enriched sprouts.
}

Keywords: adzuki bean, sprout, enrichment, iron, protein, bioaccessibility

\section{Introduction}

Iron $(\mathrm{Fe})$ is an essential element for cellular homeostasis, oxygen transport, DNA synthesis, and energy metabolism as well as a cofactor for enzymes of the mitochondrial respiratory chain and nitrogen fixation. In human nutrition, Fe is used mainly in the hemoglobin synthesis in erythrocytes, myoglobin in the muscles, and cytochromes in the liver. ${ }^{1}$ One of the main public health concerns in developing countries is Fe deficiency, ${ }^{2}$ where ca. $40 \%$ of the world population have Fe deficiency or low hemoglobin levels. ${ }^{3}$ According to the US Food and Drug Administration (FDA) regulations, the recommended dietary allowance for $\mathrm{Fe}$ is $18 \mathrm{mg}$. ${ }^{4}$

Leguminous plants have major social and economic importance, being one of the main sources of proteins, plant-derived micronutrients, and minerals for the population. ${ }^{5}$ Furthermore, beans are the vegetable sources with the largest total $\mathrm{Fe}$ amount. Nonetheless, knowledge about the total elemental concentration of foods cannot result in information on the nutritional, toxicological, and essentiality characteristics because such studies have shown

*e-mail: jnaozuka@gmail.com that legumes contain a low concentration of $\mathrm{Fe}$ species available for absorption and hence are ineffective sources for rectifying nutritional Fe deficiencies. ${ }^{6}$ Accordingly, the strategies aimed at increasing the levels of essential elements, such as $\mathrm{Fe}$, in agricultural products can help to minimize deficiencies, mainly in the populations of developing countries.

Alternatives that facilitate adjustment to new healthy, sustainable, and pesticides-free nutrition are becoming increasingly important. Consumption of sprouted foods is a segment that should be promoted in nutrition and can be established even in urban areas. ${ }^{7}$ Sprout production is a simple and fast germination process, which is extremely inexpensive. Although several kinds of seeds may be eaten as sprouts, adzuki beans (Vigna angularis) and mung beans (Vigna radiata) are usually preferred and are commonly used for the sprout production. ${ }^{8}$ The adzuki bean seeds containing ca. $50 \%$ starch and $25 \%$ protein are among the 12 most important legume products grown worldwide. ${ }^{9-12}$

Additionally, the germination has been identified as an effective technology that improves the quality and nutritional value of grain legumes. ${ }^{13}$ Some studies have clearly shown that it is possible to enrich sprouts with essential elements to combat nutritional deficiencies. ${ }^{14-16}$ 
Effective ways to increase Fe levels in plants include spraying with a Fe salt solution, ${ }^{17}$ adding $\mathrm{Fe}$ salts to the culture medium, ${ }^{18}$ and hydroponic cultivation of seeds in a nutrient-enriched solution. ${ }^{19}$ The fertilizers commonly used to enrich agricultural crops contain $\mathrm{FeSO}_{4} \cdot 7 \mathrm{H}_{2} \mathrm{O}$, $\mathrm{FeCl}_{3} \cdot 6 \mathrm{H}_{2} \mathrm{O}$, or a chelate of $\mathrm{Fe}^{20}$ On the other hand, the absorption and translocation of $\mathrm{Fe}$ in plants are limited, where superoxide and hydrogen peroxide production in cells during reduction of molecular oxygen is catalyzed by $\mathrm{Fe}^{2+}$ and $\mathrm{Fe}^{3+}$, which can damage cellular components, such as the DNA, proteins, lipids, and sugars. Thus, the Fe uptake by plants is highly regulated to prevent an excess. ${ }^{21}$ Therefore, to select the best source of Fe to enrich a food product, a technologist should also consider the influence of the Fe species added to the culture medium on elemental translocation to the edible part of the plant, as well as the physical and chemical characteristics of the plant, in order to maintain the product intake and $\mathrm{Fe}$ bioavailability.

Therefore, in this work was (i) produced Fe-enriched adzuki bean sprouts; (ii) evaluated the Fe accumulation and translocation in plants in various culture media $\left(\mathrm{FeCl}_{3}, \mathrm{FeSO}_{4}\right.$, and $\mathrm{Fe}^{\mathrm{III}}$-ethylenediaminetetraacetic acid (Fe ${ }^{\mathrm{III}}$-EDTA)) enriched with different $\mathrm{Fe}$ masses $(500,1000,2000$, and $3000 \mu \mathrm{g})$; and (iii) evaluated the effects of the enrichment by means of $3000 \mu \mathrm{g}$ Fe ${ }^{\mathrm{III}}$-EDTA: on the distribution of $\mathrm{Ca}, \mathrm{Cu}, \mathrm{Fe}, \mathrm{K}, \mathrm{P}, \mathrm{Mg}$, $\mathrm{S}$, and $\mathrm{Zn}$ in different parts of the plant (roots, stems, and cotyledons); on protein concentrations (albumins, globulins, prolamins, and glutelins) and their association with $\mathrm{Fe}$ in the edible part of the plant (stems); and on Fe bioaccessibility in the edible part of the plant (stems).

\section{Experimental}

\section{Instrumentation}

For the quantification of elements $(\mathrm{Ca}, \mathrm{Cu}, \mathrm{Fe}, \mathrm{K}$, $\mathrm{Mg}, \mathrm{P}, \mathrm{S}$, and $\mathrm{Zn}$ ), an inductively coupled plasma optical emission spectrometer (model iCAP 6300 Duo, Thermo Fisher Scientific, England), equipped with axial and radial viewed plasma was used throughout the study. The spectrometer was equipped with a charge-injection device (CID), allowing for analyses from 166.25 to $847.00 \mathrm{~nm}$. An Echelle polychromator was purged with argon, a 27.12 MHz radiofrequency source and plasma axial-view were used. A Meinhard nebulizer combined with a cyclonic spray chamber served as the sample introduction system. The injector tube diameter of the torch was $2.0 \mathrm{~mm}$.

For the Fe quantification in water, $\mathrm{NaCl}\left(1.0 \mathrm{~mol} \mathrm{~L}^{-1}\right)$, ethanol $(70 \% \mathrm{v} / \mathrm{v})$ and $\mathrm{NaOH}\left(1.0 \mathrm{~mol} \mathrm{~L}^{-1}\right)$ extracts, a ZEEnit 60 model atomic absorption spectrometer
(Analytikjena AG, Germany) equipped with a transversely heated graphite atomizer, pyrolytically coated graphite tube, and transversal Zeeman-effect background correction were used. The spectrometer was operated with a hollow cathode lamp operated by a wavelength, lamp current and slit equal to $248.3 \mathrm{~nm}, 4 \mathrm{~mA}$, and $0.8 \mathrm{~nm}$, respectively. All measurements were based on integrated absorbance values. A $10 \mu \mathrm{L}$ aliquot of different supernatants was introduced into the graphite tube without adding a chemical modifier. The instrumental conditions for the spectrometer and the heating program are shown in Table $1 .{ }^{22}$ Argon 99.998\%, v/v (Air Liquide Brasil, Brazil) was used as a protective and purging gas.

Table 1. Heating program for Fe determination by GF AAS

\begin{tabular}{lcccc}
\hline Step & $\begin{array}{c}\text { Temperature / } \\
{ }^{\circ} \mathrm{C}\end{array}$ & $\begin{array}{c}\text { Ramp / } \\
\left({ }^{\circ} \mathrm{C} \mathrm{s}^{-1}\right)\end{array}$ & Hold / s & $\begin{array}{c}\text { Argon flow / } \\
\left(\mathrm{mL} \mathrm{min}^{-1}\right)\end{array}$ \\
\hline Drying & 100 & 10 & 15 & 1000 \\
Drying & 130 & 10 & 20 & 1000 \\
Pyrolysis & 1200 & 100 & 20 & 1000 \\
Atomization & 2300 & 2300 & 5 & 0 \\
Cleaning & 2500 & 1200 & 2 & 1000 \\
\hline
\end{tabular}

An Ultrospec 2100 Pro spectrophotometer (Biochrom Ltd., UK), equipped with a xenon lamp and with a 190-900 $\mathrm{nm}$ range wavelength was used for protein quantification at $595 \mathrm{~nm}$. A centrifuge (Q222TM model, Quimis, Brazil), was used for the phase separation.

The digestion of samples and standard reference materials [peach leaves (SRM 1547) from the National Institute of Standards and Technology (NIST)] were carried out in a closed-vessel microwave system (Speedwave-4, Germany) equipped with 16 fluoropolymer vessels and a ceramic vessel jacket. For simulated gastrointestinal digestion, a water bath at $36{ }^{\circ} \mathrm{C}$ was used for $120 \mathrm{~min}$ (Q226M2 model, Quimis, Brazil).

For preliminary preparation of the samples, different parts of the adzuki bean sprouts were dried in a freeze dryer (Thermo Fisher Scientific, England). Homogenization of the culture medium was performed by means of an orbital shaker (model 0225M, Quimis, Brazil).

\section{Reagents and samples}

A $500 \mathrm{~g}$ package of adzuki bean seeds was purchased at the local market of São Paulo, Brazil. The producers assert that the geographic origin is São Paulo.

All solutions were prepared from analytical reagentgrade chemicals, with high-purity deionized water from a Milli-Q water purification system (Millipore, USA) as a 
solvent. Analytical grade $65 \%(\mathrm{~m} / \mathrm{v}) \mathrm{HNO}_{3}$, distilled in a quartz sub-boiling still (Marconi, Brazil), and 30\% (m/v) $\mathrm{H}_{2} \mathrm{O}_{2}$ (Merck, Germany) were used for the sample digestion.

A solution containing $1.0 \mathrm{mg} \mathrm{L}^{-1} \mathrm{Mg}$ (Merck, USA) was utilized to assess the robustness of the spectrometer. ${ }^{23}$ Titrisol standard solutions of $1000 \mathrm{mg} \mathrm{L}{ }^{-1}$ for $\mathrm{Ca}\left(\mathrm{CaCl}_{2}\right)$, $\mathrm{Cu}\left(\mathrm{CuCl}_{2}\right), \mathrm{Fe}\left(\mathrm{FeCl}_{3}\right), \mathrm{K}(\mathrm{KCl}), \mathrm{Mg}\left(\mathrm{MgCl}_{2}\right), \mathrm{P}\left(\mathrm{H}_{3} \mathrm{PO}_{4}\right)$, $\mathrm{S}\left(\mathrm{H}_{2} \mathrm{SO}_{4}\right)$, and $\mathrm{Zn}\left(\mathrm{ZnCl}_{2}\right)$ (Merck, USA) were applied to prepare the reference analytical solutions, after dilution in $\mathrm{HNO}_{3} 0.1 \%$ (v/v) for elemental analysis by inductively coupled plasma optical emission spectrometry (ICP OES) and $\mathrm{FeCl}_{3}$ for determining the $\mathrm{Fe}$ content by graphite furnace atomic absorption spectrometry (GF AAS).

For the sequential extraction, the following reagents (Merck, USA) were used: acetone, chloroform, ethanol, methanol, $\mathrm{NaCl}$, and $\mathrm{NaOH}$.

The total protein concentration in the extractants was assayed by means of the Bradford's reagent (BioAgency, Brazil), diluted five-fold with deionized water before the analysis. The stock solution for construction of a standard curve was prepared by dissolving $4.0 \mathrm{mg}$ of ovalbumin (BioAgency, Brazil) in $2.0 \mathrm{~mL}$ of deionized water with vortex stirring for $2 \mathrm{~min}$. The solution was then diluted 10 -fold with deionized water.

Gastrointestinal fluids were prepared using $\mathrm{NaCl}$ (Merck, Germany), pepsin (Sigma-Aldrich, USA), $\mathrm{HCl}$ (Merck, Germany), $\mathrm{NaHCO}_{3}$ (Reagen, Brazil), $\mathrm{K}_{2} \mathrm{HPO}_{4}$ (Synth, Brazil), $\mathrm{NaOH}$ (Merck, Germany), pancreatin (Sigma-Aldrich, USA), and bile salts (Sigma-Aldrich, USA). A $3 \%(\mathrm{~m} / \mathrm{v})$ solution of $\mathrm{NaHCO}_{3}$ (Reagen, Brazil) was employed to adjust $\mathrm{pH}$. The dialysis procedure was performed using cellulose membranes (Sigma-Aldrich, USA) in $32 \mathrm{~mm}$ tubes with $12.4 \mathrm{kDa}$ porosity. For the treatment of the membranes, $\mathrm{Na}_{2} \mathrm{~S}$ (Merck, Germany) $0.3 \%(\mathrm{~m} / \mathrm{v})$ and $\mathrm{H}_{2} \mathrm{SO}_{4}$ (Merck, Germany) $0.2 \%(\mathrm{v} / \mathrm{v})$ solutions were used.

Seeds were sterilized with $\mathrm{NaClO}$ (Sigma-Aldrich, USA). Fe salt solutions $\left[\mathrm{FeCl}_{3} \cdot 6 \mathrm{H}_{2} \mathrm{O}, \mathrm{FeSO}_{4} \cdot 7 \mathrm{H}_{2} \mathrm{O}\right.$, or ethylenediaminetetraacetic acid ferric sodium

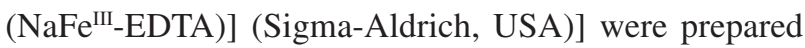
for the enrichment procedure.

\section{Procedures}

Cultivation of sprouts and preliminary sample preparation

Cultivation of adzuki bean sprouts was carried out in triplicate for each treatment. The adzuki bean seeds were first cleaned with deionized water. After sterilization of the seeds for $5 \mathrm{~min}$ in $\mathrm{NaClO}(12 \% \mathrm{v} / \mathrm{v}),{ }^{24}$ the seeds (ca. $5 \mathrm{~g}$ ) were cleaned again and left to soak in deionized water (ca. $200 \mathrm{~mL}$ ) at room temperature for $24 \mathrm{~h}$, to promote the breaking of seed dormancy. ${ }^{25}$ Absorbent cotton (ca. $3 \mathrm{~g}$ ) was spread over the base of a glass container previously decontaminated with $\mathrm{HNO}_{3}(10 \% \mathrm{v} / \mathrm{v})$. The seeds were cultivated in a portable greenhouse in the dark and longday temperature conditions at ca. $27^{\circ} \mathrm{C}$ during the day and $18^{\circ} \mathrm{C}$ at night at $70 \%$ relative humidity, with a total culture period of 13 days.

During the germination, all the sprouts were soaked once a day with $20 \mathrm{~mL}$ of deionized water. The germination of adzuki beans seeds was carried out with deionized water alone (control group) or with Fe salt solutions $\left[\mathrm{FeCl}_{3} \cdot 6 \mathrm{H}_{2} \mathrm{O}\right.$, $\mathrm{FeSO}_{4} \cdot 7 \mathrm{H}_{2} \mathrm{O}$, and $\mathrm{NaFe}^{\mathrm{III}}$-EDTA containing 500, 1000, 2000 , or $3000 \mu \mathrm{g}$ of $\mathrm{Fe}$ ( $20 \mathrm{~mL}$ of Fe salt solutions)]. The total germination period was 13 days.

The adzuki bean sprouts were collected and washed with deionized water, and different parts of the plant (roots, stems, and cotyledons) were separated. They were dried by lyophilization (ca. 2 days) and ground by means of a pestle and mortar (decontaminated) after freezing the samples in liquid nitrogen.

\section{Sample digestion}

To determine the total levels of the elements $(\mathrm{Ca}, \mathrm{Cu}$, $\mathrm{Fe}, \mathrm{K}, \mathrm{Mg}, \mathrm{P}, \mathrm{S}$, and $\mathrm{Zn}$ ), different parts of the plant (roots, stems, and cotyledons) or SRM were subjected to acid digestion in a closed-vessel microwave system. Samples masses of ca. $250 \mathrm{mg}$ were digested with $2 \mathrm{~mL} \mathrm{HNO}_{3}+$ $1 \mathrm{~mL} \mathrm{H}_{2} \mathrm{O}_{2}+3 \mathrm{~mL} \mathrm{H}_{2} \mathrm{O} .{ }^{26}$ The heating program consisted of three steps (temperature $/{ }^{\circ} \mathrm{C}$; ramp / min; hold / min): (i) $(140 ; 5 ; 1)$; (ii) $(180,4,5)$; and (iii) $(220,4,10)$. The system was cooled by forced ventilation for $20 \mathrm{~min}$. The final volume was $10 \mathrm{~mL}$, completed with deionized water, and the digestion procedures were performed in duplicate (roots) or in triplicate (stems and cotyledons).

Quantification of $\mathrm{Ca}, \mathrm{Cu}, \mathrm{Fe}, \mathrm{K}, \mathrm{Mg}, \mathrm{P}, \mathrm{S}$, and $\mathrm{Zn}$ by ICP OES

The Mg (II) $280.265 / \mathrm{Mg}$ (I) $285.208 \mathrm{~nm}$ emission line intensity ratio was used to assess the robustness of the ICP system. ${ }^{23,27}$ A good response was observed with the instrumental parameters of the ICP OES analysis shown in Table 2. Under such conditions, the $\mathrm{Mg}$ (II)/Mg (I) ratios were 17.0 for the axial view.

The calibration was carried out by means of analytical solutions prepared in a medium with the same acid concentration as that used in the digestion procedure: Ca: $1.75-224 \mathrm{mg} \mathrm{L}^{-1} ; \mathrm{Fe}, \mathrm{K}, \mathrm{Mg}, \mathrm{P}$, and $\mathrm{S}: 1.25-160 \mathrm{mg} \mathrm{L}^{-1}$; $\mathrm{Zn}: 0.06-8 \mathrm{mg} \mathrm{L}^{-1}$; and $\mathrm{Cu}: 0.02-3.2 \mathrm{mg} \mathrm{L}^{-1}$.

The matrix effect was evaluated using the standard addition method and recovery test applied to digested solutions (root, stems, and cotyledons samples). The concentrations of the analytical solution added to 
Table 2. Instrumental conditions for $\mathrm{Ca}, \mathrm{Cu}, \mathrm{Fe}, \mathrm{K}, \mathrm{Mg}, \mathrm{P}, \mathrm{S}$, and $\mathrm{Zn}$ determination by ICP OES

\begin{tabular}{lc}
\hline Power / W & 1250 \\
\hline Nebulizer & Meinhard \\
cyclonic \\
Spray chamber & 15 \\
Plasma gas flow / $\left(\mathrm{L} \mathrm{min}^{-1}\right)$ & 1.0 \\
Intermediate gas flow / $\left(\mathrm{L} \mathrm{min}^{-1}\right)$ & 0.45 \\
Nebulizer gas flow / $\left(\mathrm{L} \mathrm{min}^{-1}\right)$ & 1.5 \\
Sample introduction / $\left(\mathrm{L} \mathrm{min}^{-1}\right)$ & Analytical wavelength / nm (axial view) \\
\hline & $\mathrm{Mg}$ (II) 279.8 \\
Ca (II) 318.1 & $\mathrm{P}$ (I) 213.6 \\
$\mathrm{Cu}$ (I) 324.7 & $\mathrm{~S}$ (I) 180.7 \\
$\mathrm{Fe}$ (II) 259.8 & $\mathrm{Zn}$ (I) 213.8 \\
$\mathrm{~K}$ (I) 769.8 & \\
\hline
\end{tabular}

a(I): atomic line; (II): ionic line.

the sample were $56(\mathrm{Ca}), 0.8(\mathrm{Cu}), 40(\mathrm{Fe}), 40(\mathrm{~K})$, $20(\mathrm{Mg}), 40(\mathrm{P}), 40(\mathrm{~S}), 2(\mathrm{Se})$ and $2 \mathrm{mg} \mathrm{L}^{-1}(\mathrm{Zn})$, after acid digestion in a microwave oven or simulated gastrointestinal digestion.

Peach leaves (SRM 1547) were subjected to acid digestion and were used to check the accuracy of the analytical method applied to determination of total concentrations.

\section{Sequential extraction and quantification of $\mathrm{Fe}$ associated} with albumins, globulins, prolamins, and glutelins

A sequential extraction procedure described by Naozuka and Oliveira ${ }^{28}$ was utilized in this study, with some modifications. Approximately $200 \mathrm{mg}$ of dried and ground stems (control and enriched with $3000 \mu \mathrm{g}$ of $\mathrm{Fe}^{\mathrm{III}}$-EDTA groups) were used for the solid-liquid extraction with the following extractors and extraction periods, sequentially: methanol/chloroform mixture $(3 \mathrm{~mL}, 1: 2 \mathrm{v} / \mathrm{v} ; 30 \mathrm{~min})$, acetone $(3 \mathrm{~mL}, 70 \% \mathrm{v} / \mathrm{v} ; 30 \mathrm{~min}),{ }^{29}$ deionized water ( $4 \mathrm{~mL} ; 30 \mathrm{~min}), \mathrm{NaCl}\left(2 \mathrm{~mL}, 1 \mathrm{~mol} \mathrm{~L}^{-1}\right.$; $15 \mathrm{~min})$, ethanol ( $1 \mathrm{~mL}, 75 \% \mathrm{v} / \mathrm{v} ; 30 \mathrm{~min})$, and $\mathrm{NaOH}$ $\left(10 \mathrm{~mL}, 1 \mathrm{~mol} \mathrm{~L}^{-1} ; 60 \mathrm{~min}\right)$, in which the mixture of a solid sample and extractants was prepared using an orbital shaker at $1520 \times \mathrm{g}$. The methanol/chloroform and acetone extractions were consecutively repeated 3 times, but 1 time for ethanol, 3 times for water, 4 times for $\mathrm{NaCl}$, and 5 times for $\mathrm{NaOH}$. The solid phase separation at each step of the sequential extraction was carried out by centrifugation at $2778 \times \mathrm{g}$ for $10 \mathrm{~min}$.

The protein quantification was performed by the Bradford method. ${ }^{30}$ Spectrophotometer calibration was performed by means of analytical reference solutions of 4 , $6,8,10,12,16$, and $20 \mu \mathrm{g}$ of ovalbumin in $1.0 \mathrm{~mL}$ of the
Bradford reagent. Water, $\mathrm{NaCl}$, and $\mathrm{NaOH}$ extracts were diluted 2- to 40-fold in deionized water, except for ethanol extracts (without dilution).

The Fe determination was carried out by GF AAS in water, $\mathrm{NaCl}$, ethanol, and $\mathrm{NaOH}$ extracts. The instrument calibration was carried out using analytical solutions with concentrations ranging from 10 to $80 \mu \mathrm{g} \mathrm{L}^{-1}$ in $0.1 \% \mathrm{v} / \mathrm{v}$ $\mathrm{HNO}_{3}$. All the supernatants were diluted 2- to 20-fold beforehand in deionized water and no chemical modifier was used. The chemical interferences were assessed by an addition-and-recovery test, adding a solution of $20 \mu \mathrm{g} \mathrm{L} \mathrm{L}^{-1}$ $\mathrm{Fe}$ in the different extracts.

\section{An assay of simulated gastrointestinal digestion}

The in vitro gastrointestinal digestion procedure using fluids prepared according to U.S. Pharmacopeia \& National XXIV recommendations ${ }^{31}$ was employed to evaluate the Fe bioaccessibility. The gastric juice was prepared by dissolving $0.2 \mathrm{~g}$ of $\mathrm{NaCl}$ and $0.32 \mathrm{~g}$ of pepsin in water, $7 \mathrm{~mL}$ of $\mathrm{HCl}$ at $10 \%(\mathrm{v} / \mathrm{v})$ was subsequently added, and this solution was diluted to $100 \mathrm{~mL}$ with deionized water. This solution was maintained at $\mathrm{pH}$ 1.5. Then, $3 \mathrm{~g}$ of $\mathrm{NaHCO}_{3}$ was dissolved in $100 \mathrm{~mL}$ of high-purity deionized water to obtain a $3 \%$ solution $(\mathrm{m} / \mathrm{v})$. The intestinal fluid was prepared by dissolving $0.680 \mathrm{~g}$ of $\mathrm{K}_{2} \mathrm{HPO}_{4}, 1.0 \mathrm{~g}$ of pancreatin, $1.25 \mathrm{~g}$ of bile salts, in $7.7 \mathrm{~mL}$ of $\mathrm{NaOH}$ $\left(0.2 \mathrm{~mol} \mathrm{~L}^{-1}\right)$. This solution was diluted to $100 \mathrm{~mL}$ and final $\mathrm{pH}$ was 6.8 with $\mathrm{NaOH}$.

For an in vitro gastrointestinal digestion procedure, it was added $3.0 \mathrm{~mL}$ of the artificial gastric juice ( $\mathrm{pH} 1.5)$ to $200 \mathrm{mg}$ of the edible part of adzuki bean plant (stem). The mixture was shaken continuously in a thermostatic bath with horizontal linear shaking $(100 \mathrm{~Hz})$ at $36^{\circ} \mathrm{C}$ for $2 \mathrm{~h}$. To adjust the $\mathrm{pH}$ to 6.8 , it was added $0.4 \mathrm{~mL}$ of $\mathrm{NaHCO}_{3} 3 \%(\mathrm{~m} / \mathrm{v})$. Then, $3.0 \mathrm{~mL}$ of intestinal fluid ( $\mathrm{pH} 6.5$ ) was added, and the extract solution was shaken again using the same conditions as in the gastric digestion step, the samples were placed in an ice bath to stop the enzymatic activity (and consequently the simulated digestion) and were centrifuged to separate the supernatant. These supernatants were analyzed by ICP OES, resulting in the soluble fraction of $\mathrm{Fe}$.

The dialysis procedure was performed to simulate nutrient absorption by human organisms. The membranes were initially treated before the dialysis step, they were washed in water for 3-4 $\mathrm{h}$ for the removal of glycerol, washed in $\mathrm{Na}_{2} \mathrm{~S}(0.3 \% \mathrm{~m} / \mathrm{v})$ at $80{ }^{\circ} \mathrm{C}$ for $1 \mathrm{~min}$, and stored in $\mathrm{H}_{2} \mathrm{SO}_{4}(3 \% \mathrm{v} / \mathrm{v})$. The supernatants $(2 \mathrm{~mL})$ were added into bags made from cellulose membranes, tied with polyethylene tapes, and immersed into tubes filled with $30 \mathrm{~mL}$ of water. After $12 \mathrm{~h}$, the membrane was carefully opened, and the solution was collected from inside and 
analyzed by ICP OES, and was designated as a dialyzed fraction of Fe. The bioaccessible fraction was calculated by subtracting the element's concentration in the dialyzed fraction from that in the soluble fraction. ${ }^{32}$

Before the sample analyses by ICP OES, the soluble and dialyzed fractions were centrifuged and an aliquot of $3 \mathrm{~mL}$ of the supernatants was mixed with $0.5 \mathrm{~mL}$ of $10 \% \mathrm{v} / \mathrm{v} \mathrm{HNO}_{3}$, and the volume was increased to $5 \mathrm{~mL}$ with deionized water. The Fe determination was conducted at the above-mentioned robustness-tested settings of the spectrometer.

\section{Statistical analyses}

Cultivation of the adzuki bean sprouts (all treatments) and analyses were carried out in triplicate.

Statistical significance of differences $(p<0.05)$ in the results on Fe translocation, in each plant part separately, was analyzed in the Statistica 12.0 System Software (StatSoft, Inc., Tulsa, OK), using one-way analysis of variance (ANOVA). Student's $t$-test at a 95\% confidence limit was applied to the different groups of Fe-enriched sprouts that showed significant differences $(p<0.05)$, for comparison of the Fe-enriched and control groups.

In the edible part of the plant (sprouts), the obtained results (total concentrations of elements, proteins, and Fe-proteins) were compared by Student's $t$-test at a 95\% confidence limit.

\section{Results and Discussion}

The method for determination of $\mathrm{Ca}, \mathrm{Cu}, \mathrm{Fe}, \mathrm{K}, \mathrm{Mg}, \mathrm{P}, \mathrm{S}$, and $\mathrm{Zn}$ by ICP OES

The limits of detection (LODs) were calculated by means of the equation LOD $=3 \times \mathrm{BEC} \times \mathrm{RSD} / 100$, where $\mathrm{BEC}=\mathrm{C}_{\mathrm{rs}} / \mathrm{SBR}, \mathrm{SBR}=\left(\mathrm{I}_{\mathrm{rs}}-\mathrm{I}_{\text {blank }}\right) / \mathrm{I}_{\text {blank }}\left(\mathrm{C}_{\mathrm{rs}}\right.$ is the concentration of the multielemental reference solution, $\mathrm{I}_{\mathrm{rs}}$ and $\mathrm{I}_{\text {blank }}$ are the emission intensities for the multielemental reference and blank solutions, respectively), and RSD is the relative standard deviation for 10 consecutive measurements of a blank solution. ${ }^{26,33,34}$ For all analytes of interest, the LOD ranged from $0.01(\mathrm{Zn})$ to $0.54 \mathrm{mg} \mathrm{g}^{-1}(\mathrm{~K})$.

The absence of chemical interference was verified by the addition-and-recovery test, and the recovery rates ranged from 86 (S) to $116 \%$ (Zn). According to NBR ISO/IEC $17025,{ }^{35}$ the recovery tolerance ranges from 80 to $120 \%$. Additionally, the accuracy was assessed by analyzing the SRM 1547, and it was attained good agreement, as indicated by Student's $t$-test at the 95\% confidence limit; it was obtained recoveries (comparison between certified and experimental results) that ranged from 96.5 (S) to $101 \%$ (P).
Uptake, translocation, and accumulation of $\mathrm{Fe}$ in adzuki bean sprouts: enrichment via different $\mathrm{Fe}$ compounds

The Fe concentration in different parts of the adzuki bean sprouts (root, cotyledon, and stem) in control and enrichment groups $\left(\mathrm{FeCl}_{3} \cdot 6 \mathrm{H}_{2} \mathrm{O}, \mathrm{FeSO}_{4} \cdot 7 \mathrm{H}_{2} \mathrm{O}\right.$, and $\mathrm{NaFe}{ }^{\mathrm{III}}$-EDTA $)$ with different masses of $\mathrm{Fe}(500,1000,2000$, or $3000 \mu \mathrm{g})$ added to the culture medium are shown in Table 3 . The standard deviations (SD) are related to the expanded error associated with instrumental measurements $(n=3)$ and the two digested solutions of each part of the plant.

Table 3. Iron translocation from the root, cotyledon, and stem of the adzuki beans plant cultivated in Fe-enriched medium with different masses of iron added to the culture medium

\begin{tabular}{|c|c|c|c|c|}
\hline \multirow{2}{*}{\multicolumn{5}{|c|}{$\begin{array}{c}\text { Iron concentration } \pm \text { standard deviation }(\mathrm{n}=3) /\left(\mu \mathrm{g} \mathrm{g}^{-1}\right) \\
\text { Root }\end{array}$}} \\
\hline & & & & \\
\hline & $500 \mu \mathrm{g}$ & $1000 \mu \mathrm{g}$ & $2000 \mu \mathrm{g}$ & $3000 \mu \mathrm{g}$ \\
\hline $\mathrm{FeSO}_{4}$ & $150 \pm 4^{b}$ & $173 \pm 1^{b}$ & ND & ND \\
\hline $\mathrm{FeCl}_{3}$ & $199 \pm 1^{\mathrm{b}}$ & $340 \pm 1^{\mathrm{b}}$ & ND & ND \\
\hline $\mathrm{Fe}^{\mathrm{III}}$-EDTA & $65 \pm 3^{\mathrm{a}}$ & $79 \pm 1^{\mathrm{b}}$ & $143 \pm 12^{\mathrm{b}}$ & $145 \pm 1^{\mathrm{b}}$ \\
\hline \multirow[t]{3}{*}{ Control } & \multicolumn{4}{|c|}{$66 \pm 1^{\mathrm{a}}$} \\
\hline & \multicolumn{4}{|c|}{ Cotyledon } \\
\hline & $500 \mu \mathrm{g}$ & $1000 \mu \mathrm{g}$ & $2000 \mu \mathrm{g}$ & $3000 \mu \mathrm{g}$ \\
\hline $\mathrm{FeSO}_{4}$ & $198 \pm 1^{\mathrm{b}}$ & $156 \pm 1^{\mathrm{b}}$ & ND & ND \\
\hline $\mathrm{FeCl}_{3}$ & $144 \pm 1^{\mathrm{b}}$ & $366 \pm 1^{b}$ & ND & ND \\
\hline $\mathrm{Fe}^{\mathrm{III}}$-EDTA & $80 \pm 1^{\mathrm{b}}$ & $100 \pm 1^{b}$ & $244 \pm 1^{\mathrm{b}}$ & $332 \pm 22^{b}$ \\
\hline \multirow[t]{3}{*}{ Control } & \multicolumn{4}{|c|}{$54 \pm 2^{\mathrm{a}}$} \\
\hline & \multicolumn{4}{|c|}{ Stem } \\
\hline & $500 \mu \mathrm{g}$ & $1000 \mu \mathrm{g}$ & $2000 \mu \mathrm{g}$ & $3000 \mu \mathrm{g}$ \\
\hline $\mathrm{FeSO}_{4}$ & $84 \pm 3^{a}$ & $126 \pm 2^{b}$ & ND & ND \\
\hline $\mathrm{FeCl}_{3}$ & $89 \pm 1^{\mathrm{a}}$ & $124 \pm 1^{\mathrm{b}}$ & ND & ND \\
\hline $\mathrm{Fe}^{\mathrm{III}}$-EDTA & $103 \pm 5^{b}$ & $110 \pm 2^{b}$ & $125 \pm 1^{\mathrm{b}}$ & $156 \pm 2^{b}$ \\
\hline Control & \multicolumn{4}{|c|}{$89 \pm 1^{\mathrm{a}}$} \\
\hline
\end{tabular}

${ }^{\mathrm{a}, \mathrm{b}}$ Different letters between the control and enrichment results of the same plant part (root, cotyledon, or stem) indicate significant differences when compared to the control group $(p<0.05)$. ND: not determined.

After 13 days, the control and Fe-enriched sprouts showed similarities in color, odor, and length. Nevertheless, using $\mathrm{FeCl}_{3}$ or $\mathrm{FeSO}_{4}$ in the culture medium at $\mathrm{Fe}$ concentrations higher than $1000 \mu \mathrm{g}$, a low sprout yield was observed: the germination process was inhibited, and the sprouts were intoxicated and unable to grow. Additionally, after the Fe enrichment via the chloride and sulfate, Fe accumulated both in the roots and cotyledon of the plants. The Fe translocation was not favored; instead, it noted a 39\% increase when $1000 \mu \mathrm{g}$ of Fe was added to the culture medium. 
After the enrichment via Fe ${ }^{\text {III-EDTA, the } \mathrm{Fe}}$ concentration in the roots did not show a significant alteration when compared to the control and enrichment $(500 \mu \mathrm{g})$ groups. In addition, the accumulation of $\mathrm{Fe}$ in the roots and cotyledons was less favored (500 and $1000 \mu \mathrm{g} \mathrm{Fe}$ ) when compared to the enrichment via $\mathrm{FeCl}_{3}$ and $\mathrm{FeSO}_{4}$. On the other hand, the highest enrichment potential of the edible part of the plant was observed after cultivation with Fe ${ }^{\mathrm{III}}$-EDTA mass up to $3000 \mu \mathrm{g}$.

It should be pointed out that the Fe complex (coordination compound) was found to be less toxic and favored the translocation of Fe because (i) Fe enrichment of the culture medium with $3000 \mu \mathrm{g}$ Fe $\mathrm{FII}^{\mathrm{III}}$-EDTA resulted in a $75 \%$ increase in the total $\mathrm{Fe}$ concentration in the stems; (ii) Fe accumulated less in the roots when compared to the other Fe salts; and (iii) produced mass and physical characteristics were similar between control and enriched sprouts.

Different Fe sources such as ferrous sulfate, ferrous fumarate, $\mathrm{Fe}^{\mathrm{III}}$-EDTA, reduced $\mathrm{Fe}$, electrolytic $\mathrm{Fe}$, and $\mathrm{Fe}$ glycinate chelate, with different bioavailability, can be used for the fortification food products such as wheat or corn flour. Studies have shown that the relative bioavailability can vary from 100 to $5 \%$ depending on the Fe source used for the fortification, and $\mathrm{Fe}^{\mathrm{III}}$-EDTA is the compound that shows higher bioavailability than the other compounds tested. The use of EDTA complexes has the potential to reduce the negative effect of antinutrients, such as oxalate and phytate, on mineral absorption in cereal grains and legumes. ${ }^{36}$

The absorption and translocation of $\mathrm{Fe}$ in plants are highly regulated, with reduced mobility in the xylem and incorporation into chloroplasts. ${ }^{37}$ The secretion of exudates and $\mathrm{Fe}$ accumulation in cellular organelles in roots, e.g., vacuoles, immobilize $\mathrm{Fe}$ in roots. ${ }^{38}$ Furthermore, cations absorbed by plant cells form complexes with organic compounds. Thus, due to the higher stability of the Fe ${ }^{\text {III }}$-EDTA molecule and the ability of the Fe complex to move through the root without complexation with organic compounds, this Fe complex appears to be less toxic, and the Fe translocation was favored. ${ }^{38}$

Effects of enrichment on the distribution of $\mathrm{Ca}, \mathrm{Cu}, \mathrm{Fe}, \mathrm{K}$, $\mathrm{P}, \mathrm{Mg}, \mathrm{S}$, and $\mathrm{Zn}$

The effects of enrichment on the above distributions and elemental translocation were evaluated. The $\mathrm{Ca}, \mathrm{Cu}$, $\mathrm{Fe}, \mathrm{K}, \mathrm{Mg}, \mathrm{P}, \mathrm{S}$, and $\mathrm{Zn}$ concentrations in the control and enrichment groups $\left(\mathrm{Fe}^{\mathrm{III}}\right.$-EDTA, $\left.3000 \mu \mathrm{g}\right)$ are shown in Table 4. The SD are related to the expanded error associated with instrumental measurements $(\mathrm{n}=3)$ and the two analyses of each sample.

As expected, $\mathrm{Ca}, \mathrm{K}, \mathrm{Mg}, \mathrm{P}$, and $\mathrm{S}$ can be considered the macroelements in those samples. In the roots, a decrease in the $\mathrm{Ca}(63 \%)$ and $\mathrm{Cu}(82 \%)$ concentrations and a $116(\mathrm{Fe})$, 17 (P) and 19\% (S) increase were observed as compared to the control group. In cotyledons, the concentration of most elements remained constant after the enrichment, except for $\mathrm{Ca}$ and $\mathrm{Fe}$. In the stem, the concentration of $\mathrm{Mg}, \mathrm{P}$, and $\mathrm{S}$ did not change significantly after the Fe enrichment procedure.

Elemental competition was induced in $\mathrm{Fe}$ enrichment procedures, mainly when the elements show chemical similarities (elemental or ionic characteristics). Most plants absorb selenate due to its similarity to sulfate and metabolize it via the sulfur assimilation pathway. ${ }^{39}$ In the literature, ${ }^{40}$ it was observed different antagonistic reactions in the absorption and transport of $\mathrm{Fe}$ and $\mathrm{Cu}$ in plants. The mechanism of competition in elemental translocation between $\mathrm{Cu}$ and $\mathrm{Fe}$ is not well understood, but the similarity of the ionic radii of these elements has been suggested as

Table 4. Concentration of $\mathrm{Ca}, \mathrm{Cu}, \mathrm{Fe}, \mathrm{K}, \mathrm{Mg}, \mathrm{P}, \mathrm{S}$, and $\mathrm{Zn}$ in different parts of the plant cultivated in iron enriched medium

\begin{tabular}{|c|c|c|c|c|c|c|}
\hline & \multicolumn{6}{|c|}{ Concentration \pm standard deviation $(\mathrm{n}=3)$} \\
\hline & \multicolumn{2}{|c|}{ Root } & \multicolumn{2}{|c|}{ Cotyledon } & \multicolumn{2}{|c|}{ Stem } \\
\hline & Control & $\mathrm{Fe}^{\mathrm{III}}-\mathrm{EDTA}$ & Control & $\mathrm{Fe}^{\mathrm{III}}$-EDTA & Control & $\mathrm{Fe}^{\mathrm{III}}$-EDTA \\
\hline $\mathrm{Ca} /\left(\mathrm{mg} \mathrm{g}^{-1}\right)$ & $2.53 \pm 0.06^{\mathrm{a}}$ & $0.94 \pm 0.01^{\mathrm{b}}$ & $6.3 \pm 0.2^{\mathrm{a}}$ & $4.9 \pm 0.1^{\mathrm{b}}$ & $1.0 \pm 0.2^{\mathrm{a}}$ & $0.62 \pm 0.01^{\mathrm{b}}$ \\
\hline $\mathrm{Cu} /\left(\mu \mathrm{g} \mathrm{g}^{-1}\right)$ & $38.2 \pm 0.2^{\mathrm{a}}$ & $6.8 \pm 0.8^{\mathrm{b}}$ & $11.0 \pm 0.4^{\mathrm{a}}$ & $4.4 \pm 0.8^{\mathrm{b}}$ & $20.4 \pm 0.1^{\mathrm{a}}$ & $10.7 \pm 0.8^{\mathrm{b}}$ \\
\hline $\mathrm{Fe} /\left(\mu \mathrm{g} \mathrm{g}^{-1}\right)$ & $66 \pm 1^{\mathrm{a}}$ & $143 \pm 12^{\mathrm{b}}$ & $54 \pm 2^{\mathrm{a}}$ & $244 \pm 1^{\mathrm{b}}$ & $89 \pm 1^{\text {a }}$ & $156 \pm 1^{\mathrm{b}}$ \\
\hline $\mathrm{K} /\left(\mathrm{mg} \mathrm{g}^{-1}\right)$ & $22.4 \pm 0.1^{\mathrm{a}}$ & $16.5 \pm 0.2^{\mathrm{b}}$ & $6.9 \pm 0.1^{\mathrm{a}}$ & $10.4 \pm 0.1^{\mathrm{b}}$ & $25.0 \pm 0.1^{\mathrm{a}}$ & $19.1 \pm 0.2^{\mathrm{b}}$ \\
\hline $\mathrm{Mg} /\left(\mathrm{mg} \mathrm{g}^{-1}\right)$ & $2.2 \pm 0.2^{\mathrm{a}}$ & $1.8 \pm 0.1^{\mathrm{b}}$ & $3.3 \pm 0.1^{\mathrm{a}}$ & $3.0 \pm 0.1^{\mathrm{b}}$ & $3.0 \pm 0.1^{\mathrm{a}}$ & $3.0 \pm 0.1^{\mathrm{a}}$ \\
\hline $\mathrm{P} /\left(\mathrm{mg} \mathrm{g}^{-1}\right)$ & $5.8 \pm 0.2^{\mathrm{a}}$ & $6.8 \pm 0.1^{\mathrm{b}}$ & $1.9 \pm 0.2^{\mathrm{a}}$ & $2.3 \pm 0.1^{\mathrm{b}}$ & $6.5 \pm 0.2^{\mathrm{a}}$ & $6.8 \pm 0.1^{\mathrm{a}}$ \\
\hline $\mathrm{S} /\left(\mathrm{mg} \mathrm{g}^{-1}\right)$ & $2.1 \pm 0.1^{\mathrm{a}}$ & $2.5 \pm 0.1^{\mathrm{b}}$ & $1.7 \pm 0.2^{\mathrm{a}}$ & $2.1 \pm 0.1^{\mathrm{b}}$ & $3.6 \pm 0.2^{\mathrm{a}}$ & $3.6 \pm 0.1^{\mathrm{a}}$ \\
\hline $\mathrm{Zn} /\left(\mu \mathrm{g} \mathrm{g}^{-1}\right)$ & $67.5 \pm 0.1^{\mathrm{a}}$ & $67.5 \pm 0.3^{\mathrm{a}}$ & $54.5 \pm 0.3^{\mathrm{a}}$ & $67.4 \pm 0.5^{\mathrm{b}}$ & $54.5 \pm 0.3^{\mathrm{a}}$ & $42.7 \pm 0.4^{b}$ \\
\hline
\end{tabular}

${ }_{\mathrm{a}, \mathrm{b}}$ Different letters between the elements in the same plant part indicate significant difference when compared to the control group $(p<0.05)$. 
the possible cause for such competition and antagonistic reactions..$^{38}$ In baby leaves, $\mathrm{Ca}$ enrichment promotes a reduction in $\mathrm{Mg}$ content in all biofortified vegetables, confirming the antagonism between $\mathrm{Ca}$ and $\mathrm{Mg} .{ }^{41}$ One of the reasons justifying the foliar application of $\mathrm{Zn}$ to improve nutritional quality of pea seeds is the large amounts of $\mathrm{N}$ and $\mathrm{P}$ that decrease $\mathrm{Zn}$ uptake. ${ }^{42}$

Most people consume stems of adzuki bean sprouts. Thus, people eating $115 \mathrm{~g}$ (dry mass) of sprouts cultivated in the medium enriched with $3000 \mu \mathrm{g} F$ (Fe $\mathrm{Fe}^{\mathrm{III}}$-EDTA) should achieve the recommended daily allowance $(18 \mathrm{mg})$.

\section{Effects of enrichment on the distribution of proteins and $\mathrm{Fe}$ metalloproteins}

The protein quantification was carried out by the Bradford method $^{30}$ at a wavelength of $595 \mathrm{~nm}$, and $\mathrm{Fe}$ determination in the various extracts (water, $\mathrm{NaCl}$, ethanol, and $\mathrm{NaOH}$ ) was conducted by GF AAS. The characteristic parameters of the analytical calibration curves [linear range, correlation coefficient $\left(\mathrm{R}^{2}\right)$, and sensitivity], and the LODs and limits of quantification (LOQs) are shown in Table 5. The LOD was calculated from the standard deviation of 10 measurements of the analytical blank sample $\left(3 \times \sigma_{\text {blank }}\right.$, where $\sigma$ is the standard deviation), and the LOQ was calculated as $3.3 \times$ LOD. $^{34}$ The LOD and LOQ values were obtained considering a $200 \mathrm{mg}$ sample and a final volume of 4 (water), $2\left(\mathrm{NaCl}, 1 \mathrm{~mol} \mathrm{~L}^{-1}\right.$ ), 1 (ethanol, $70 \% \mathrm{v} / \mathrm{v}$ ), and $10 \mathrm{~mL}\left(\mathrm{NaOH}, 1 \mathrm{~mol} \mathrm{~L}^{-1}\right)$.

After quantification of Fe in the different extracts (water, $\mathrm{NaCl}$, ethanol, and $\mathrm{NaOH}$ ) by GF AAS, the recovery rates were 92 (water), $82(\mathrm{NaCl}), 104$ (ethanol), and 118\% $(\mathrm{NaOH})$, indicating the absence of chemical interference during the $\mathrm{Fe}$ analysis in the various extracts.
The extractants (water, $\mathrm{NaCl}$, ethanol, and $\mathrm{NaOH}$ ) promote separation of proteins from albumins, globulins, prolamins, and glutelins, respectively. ${ }^{34}$ In adzuki beans, $84 \%$ of the proteins are albumins and globulins. Methionine, lysine, threonine, and tryptophan contents are higher in the albumin fraction than in the globulin fraction. On the other hand, the high concentration of glutamic and aspartic acids were found in the globulin fraction. ${ }^{42,43}$ The concentrations of albumin, globulin, prolamin, and glutelin, for the control and enriched (3000 $\mu \mathrm{g} \mathrm{Fe} \mathrm{Fe}^{\mathrm{III}}$-EDTA) groups are presented in Table 6. Solubility of a protein depends on amino acid composition and results from thermodynamic equilibrium between the protein-protein interaction and the protein-solvent interaction; the solubility is related to the hydrophilicity-hydrophobicity balance..$^{4,44}$ The enrichment via $\mathrm{Fe}^{\mathrm{III}}$-EDTA altered the distribution of albumins, globulins, and glutelins in the stems, thus causing a significant increase in globulin (134\%) and glutelin (48\%) concentrations and $30 \%$ downregulation of albumins.

Fe association with different proteins in the edible part of the plants (stems) determined by GF AAS is shown in Table 6. As a result of comparison with total Fe concentration (Table 4), Fe distribution among different proteins was as follows: for the control group, 8 (albumin), 0.5 (globulin), and 49\% (glutelins); and for the enrichment group, it was 10 (albumins), 0.9 (globulins), and 52\% (glutelins).

After the increase in the total $\mathrm{Fe}$ concentration with

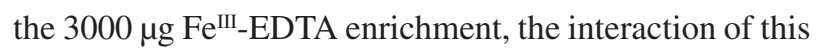
essential element with various proteins was also promoted. Additionally, the enrichment did not significantly alter the percentages of Fe associated with albumins, globulins, and glutelins in relation to the control group when compared to the total concentration of $\mathrm{Fe}$ in stems: 7.6, 0.6, 0, and

Table 5. Characteristic parameters of the analytical calibration curve, LOD, and LOQ obtained for proteins determination by Bradford method and iron determination by GF AAS

\begin{tabular}{|c|c|c|c|c|c|}
\hline \multicolumn{6}{|c|}{ Bradford method } \\
\hline Linear range / $\left(\mu \mathrm{g} \mathrm{mL}^{-1}\right)$ & $\mathrm{R}^{2}$ & Sensitivity & Analytical blank & $\mathrm{LOD} /\left(\mu \mathrm{g} \mathrm{g}^{-1}\right)$ & $\mathrm{LOQ} /\left(\mu \mathrm{g} \mathrm{g}^{-1}\right)$ \\
\hline \multirow{4}{*}{$2-12$} & \multirow{4}{*}{0.9929} & \multirow{4}{*}{0.042} & water & 6.8 & 22.4 \\
\hline & & & $\mathrm{NaCl}$ & 9.1 & 30.1 \\
\hline & & & ethanol & 6.2 & 20.5 \\
\hline & & & $\mathrm{NaOH}$ & 1.9 & 6.3 \\
\hline \multicolumn{6}{|c|}{ GF AAS } \\
\hline Linear range / $\left(\mu \mathrm{g} \mathrm{L}^{-1}\right)$ & $\mathrm{R}^{2}$ & Sensitivity & Analytical blank & $\mathrm{LOD} /\left(\mathrm{ng} \mathrm{g}^{-1}\right)$ & $\mathrm{LOQ} /\left(\mathrm{ng} \mathrm{g}^{-1}\right)$ \\
\hline \multirow{4}{*}{$10-80$} & \multirow{4}{*}{0.9995} & \multirow{4}{*}{0.004} & water & 32 & 106 \\
\hline & & & $\mathrm{NaCl}$ & 34 & 112 \\
\hline & & & ethanol & 7 & 23 \\
\hline & & & $\mathrm{NaOH}$ & 171 & 564 \\
\hline
\end{tabular}


Table 6. Proteins and Fe-proteins concentrations in edible plant part (control and enriched sprouts groups)

\begin{tabular}{|c|c|c|c|c|}
\hline & \multicolumn{4}{|c|}{ Protein concentration \pm standard deviation $(n=3) /\left(\mu \mathrm{g} \mathrm{g}^{-1}\right)$} \\
\hline & Albumin & Globulin & Prolamin & Glutelin \\
\hline Control & $66 \pm 6^{\mathrm{a}}$ & $41 \pm 5^{\mathrm{a}}$ & $<\mathrm{LOD}^{\mathrm{a}}$ & $4484 \pm 61^{\mathrm{a}}$ \\
\hline \multirow[t]{3}{*}{ Fe-enriched } & $46 \pm 9^{b}$ & $96 \pm 2^{\mathrm{b}}$ & $<\mathrm{LOD}^{\mathrm{a}}$ & $6638 \pm 67^{\mathrm{b}}$ \\
\hline & \multicolumn{4}{|c|}{ Fe-Protein concentration \pm standard deviation $(\mathrm{n}=3) /\left(\mu \mathrm{g} \mathrm{g}^{-1}\right)$} \\
\hline & Albumin & Globulin & Prolamin & Glutelin \\
\hline Control & $6.8 \pm 0.1^{\mathrm{a}}$ & $0.5 \pm 0.1^{\mathrm{a}}$ & $<\mathrm{LOD}^{\mathrm{a}}$ & $42 \pm 2^{\mathrm{a}}$ \\
\hline \multirow[t]{3}{*}{ Fe-enriched } & $16.4 \pm 0.5^{\mathrm{b}}$ & $1.4 \pm 0.1^{\mathrm{b}}$ & $<\mathrm{LOD}^{\mathrm{a}}$ & $81 \pm 2^{\mathrm{b}}$ \\
\hline & \multicolumn{4}{|c|}{ Fe-Bioaccessibility concentration \pm standard deviation $(n=3) /\left(\mu \mathrm{g} \mathrm{g}^{-1}\right)$} \\
\hline & \multicolumn{2}{|c|}{ Soluble } & \multicolumn{2}{|c|}{ Dialyzed } \\
\hline Control & \multicolumn{2}{|c|}{$46 \pm 1^{\mathrm{a}}$} & \multicolumn{2}{|c|}{$9.6 \pm 0.1^{\mathrm{a}}$} \\
\hline Fe-enriched & \multicolumn{2}{|c|}{$122 \pm 8^{b}$} & \multicolumn{2}{|c|}{$21 \pm 2^{b}$} \\
\hline
\end{tabular}

a,b Different superscripts within the same protein group indicate significant differences $(p<0.05)$ when compared to the control group.

$47.2 \%$ (control group) and 10.5, 0.6, 0, and 51.9\% (enriched group) of Fe were found to be associated with albumins, globulins, prolamins, and glutelins, respectively. Therefore, the percentage of $\mathrm{Fe}$ associated with different protein groups did not change significantly after the enrichment procedure. The main amino acids in albumins, globulins, prolamins, and glutelins, such as methionine, cysteine, glutamic acid, arginine, aspartic acid, and lysine, are rich in sulfur and charged groups. ${ }^{45-48}$ These amino acids have high affinity for ions of transition metals, such as Fe. ${ }^{49}$

It is important to point out that the fractionation experiments in this work are the first step toward nutritional information about Fe-enriched adzuki bean sprouts. The studies on the association of $\mathrm{Fe}$ with proteins are important because protein-bound elements are released during digestion, thus facilitating their absorption by the human body. Obviously, besides the chemical speciation studies, the bioaccessible and bioavailable fraction should be quantified, mainly during enrichment procedures, to identify the fraction of the compound or bioactive nutrient present in an enriched food that is available for use in physical or biochemical functions or to be stored in the organism.

\section{Effects of enrichment on Fe bioaccessibility}

In vitro assays simulating the gastrointestinal digestion of foods are relevant to the bioaccessibility studies. This procedure is more rapid, less expensive, less labor-intensive, and does not have ethical restrictions, when compared with in vivo methods..$^{50}$ Additionally, the results obtained in the in vitro procedures can help with the planning of in vivo studies, minimizing time and costs.

The Fe bioaccessibility in control group and Fe-enriched bean sprouts (Fe ${ }^{\mathrm{III}}$-EDTA) using in vitro methods was predicted by analysis of the gastrointestinal product before (soluble fraction) and after dialysis (dialyzed fraction). The bioaccessible concentration was determined by subtracting the concentration found in the dialyzed fraction from that in the soluble fraction. The results are shown in Table 6.

The soluble percentages were 52 (control group) and $78 \%$ (Fe-enriched group), and bioaccessible percentages were 79 (control group) and 83\% (Fe-enriched group), which were calculated considering, respectively, the Fe concentrations in the digested samples (Table 4) and soluble fractions (Table 6).

On the basis of the statistical data, it is possible to observe that the enrichment processes increased the concentration of soluble $\mathrm{Fe}$ and did not alter the percentage of Fe bioaccessible in terms of the soluble fraction in the control and enriched sprouts.

The bioaccessibility of an element depends not only on the matrix but also on the chemical form of the analyte. ${ }^{51}$ Therefore, the results of bioaccessibility studies show the effectiveness of the enrichment process in the bioaccessible $\mathrm{Fe}$ fraction in the edible part of the Fe-enriched plant.

The Fe bioavailability in foods varies according to the chemical species; nonheme $\mathrm{Fe}$ is found in foods of plant origin and is present in metaflavoproteins involved in oxidative metabolism, Fe-sulfur proteins, and inorganic $\mathrm{Fe}$ species $\left(\mathrm{Fe}^{\mathrm{II}}\right.$ and $\left.\mathrm{Fe}^{\mathrm{III}}\right)$, in which chemical species of $\mathrm{Fe}^{\mathrm{II}}$ are more available than $\mathrm{Fe}^{\mathrm{III}}$ because of the greater solubility in the intestinal lumen of divalent Fe species. ${ }^{52}$ In addition, only soluble nonheme Fe can be absorbed in vivo because $\mathrm{Fe}$ from vegetable sources is less available than $\mathrm{Fe}$ from animal sources owing to the presence of dietary fiber associated with oxalates, phosphates, phytates, and tannins that form insoluble complexes with nonheme $\mathrm{Fe}$ and limit elemental absorption. ${ }^{6}$ 
Feasibility of enriching sprouts with Fe: salts versus chelate

The most widely used Fe sources to correct Fe deficiencies or to promote plant enrichment are inorganic Fe forms, and ferrous sulfate is added to fertilizers. ${ }^{20,52}$ Nonetheless, Fe applied to soil can be fixed in plant roots because of various chemical reactions ${ }^{35,36}$ and due to the low mobility in plant tissue. The use of fertilizers containing inorganic forms or a chelate of $\mathrm{Fe}$ requires high concentrations to achieve a significant increase in the Fe concentration in the edible plant part. Although there is a large difference between the costs of Fe-chelated sources and Fe salts, the addition of high Fe-EDTA concentration to the culture medium promotes elemental translocation without affecting the germination process, growth, and physical characteristics of the plant. Therefore, the Fe chelate (Fe-EDTA) is the most effective compound for the production of enriched edible sprouts under the conditions described when compared to the inorganic forms $\left(\mathrm{FeCl}_{3}\right.$ and $\left.\mathrm{FeSO}_{4}\right)$.

\section{Conclusions}

The Fe enrichment of adzuki bean sprouts depends on the chemical species used in the cultivation. The addition of $\mathrm{Fe}^{\mathrm{III}}$-EDTA is the most effective procedure for the $\mathrm{Fe}$ translocation to edible parts of plants and does not significantly alter most macronutrient levels in the plant, but changes the nutritional balance in relation to the protein distribution.

The inclusion of adzuki bean sprouts enriched with $\mathrm{Fe}$ in the daily diet is a promising way to meet the daily intake recommendations of essential elements, especially Fe. In addition to the successful enrichment of bean sprouts, studies on chemical speciation are extremely important because they allow to identify and quantify the chemical forms in which the element is present in the matrix, resulting in information about the absorption, bioavailability, and bioaccessibility. Thus, consumption of sprouts with food enrichment procedures is a good alternative to pharmacological supplementation for correction of nutritional deficiencies related to specific elements in combination with products that contribute to the dissemination of healthy and functional foods.

Finally, the results obtained in this work suggest that this method of sprout enrichment with $\mathrm{Fe}$ is a promising tool for production of foods with functional properties that may be effective against anemia.

\section{Acknowledgments}

The authors are grateful to Professors Pedro Vitoriano de Oliveira and Cassiana Seimi Nomura, both from the
Chemistry Institute of the São Paulo University, for the support of the laboratory infrastructure. A. P. O. thanks Fundação de Amparo à Pesquisa do Estado de São Paulo/ FAPESP (2015/01128-6) for the fellowship provided. J. N. thanks FAPESP for the financial support (2015/15510-0).

\section{References}

1. Wijayanti, N.; Katz, N.; Curr. Med. Chem. 2004, 11, 981.

2. Cakmak, I.; Pfeiffer, W. H.; McLafferty, B.; Cereal Chem. 2010, $87,10$.

3. Moura, N. C.; Canniatti-Brazaca, S. G.; Food Sci. Technol. 2006, 26, 270.

4. Dolan, S. P.; Capar, S. G.; J. Food Compos. Anal. 2002, 15, 593.

5. Brigide, P.; Canniatti-Brazaca, S. G.; Silva, M. O.; Food Sci. Technol. 2014, 34, 493.

6. Oliveira, A. P.; Naozuka, J.; J. Braz. Chem. Soc. 2015, 26, 2144.

7. Bellenda, B.; LEISA - Revista de Agroecología 2005, 21, 29.

8. Luo, Y.; Xie, W.; Luo, F.; J. Food Sci. 2012, 77, 1023.

9. Meng, G.-T.; Ching, K.-M.; Ma, C.-Y.; Food Chem. 2002, 79, 93.

10. Sato, S.; Yamate, J.; Hori, Y.; Hatai, A.; Nozawa, M.; Sagai, M.; J. Nutr. Biochem. 2005, 16, 547.

11. Yousif, A. M.; Deeth, H. C.; Food Chem. 2003, 81, 169.

12. McGill Jr., J. A.; Mich. Dry Bean Digest 1995, 19, 4.

13. Kumar, V.; Sinha, A. K.; Makkar, H. P. S., Becker, K.; Food Chem. 2010, 120, 945.

14. Yuan, L.; Wu, L.; Yang, C.; Lv, Q.; J. Sci. Food Agric. 2013 , 93, 254.

15. Lintschinger, J.; Fuchs, N.; Moser, J.; Kuehnelt, D.; Goessler, W.; J. Agric. Food Chem. 2000, 48, 5362.

16. Wei, Y.; Shohag, M. J. L.; Ying, F.; Yang, X.; Wu, C.; Wang, Y.; Food Chem. 2013, 138, 1952.

17. Kopsell, D. A.; Sams, C. E.; Barickman, T. C.; Deyton, D. E.; HortScience 2009, 44, 438.

18. Lee, G. J.; Kang, B. K.; Kim, T. J.; Kim, J. H.; Acta Hortic. 2007, 761, 443.

19. Tsuneyoshi, T.; Yoshida, J.; Takashi, S.; J. Nutr. 2006, 136, $870 \mathrm{~S}$.

20. Hell, R.; Stephan, U. W.; Planta 2003, 216, 541.

21. Briat, J. F. In Oxidative Stress in Plants; Inze, D.; Montagu, M. V., eds.; Taylor and Francis: New York, 2002, p. 171.

22. Oliveira A. P.; Naozuka, J.; J. Braz. Chem. Soc. 2015, 26, 2144.

23. Araújo, G. C. L.; Gonzalez, M. H.; Ferreira, A. G.; Nogueira, A. R. A.; Nóbrega, J. A.; Spectrochim. Acta 2002, 57B, 2121.

24. Sangroni, E.; Machado, C. J.; LWT Food Sci. Technol. 2007, 40, 116.

25. Machado, A. L. L.; Barcelos, M. F. P.; Teixeira, A. H. R.; Ciênc. Tecnol. Aliment. 2009, 33, 1071.

26. Naozuka, J.; Vieira, E. C.; Nascimento, A. N.; Oliveira, P. V.; Food Chem. 2011, 124, 1667. 
27. Mermet, J. M.; Poussel, E.; Appl. Spectrosc. 1995, 49, 12.

28. Naozuka, J.; Oliveira, P. V.; J. Braz. Chem. Soc. 2007, $18,1547$.

29. Do, Q. D.; Angkawijaya, A. E.; Tran-Nguyen, P. L.; Huynh, L. H.; Soetaredjo, F. E.; Ismadji, S.; Ju, Y.; J. Food Drug Anal. 2014, 22, 296.

30. Bradford, M. M.; Anal. Biochem. 1976, 72, 248.

31. United States Pharmacopoeia Convention, United States Pharmacopeia In United States Pharmacopeia USP24-NF19; The United States Pharmacopeial Convention: Rockville, MD, 2000, p. 2235.

32. Nascimento, A. N.; Naozuka, J.; Oliveira, P. V.; Microchem. J. 2010, 96, 58.

33. International Union of Pure and Applied Chemistry (IUPAC); Spectrochim. Acta 1978, 33B, 241.

34. Silva, J. C. J.; Cadore, S.; Nóbrega, J. A.; Food Addit. Contam. 2007, 24, 130.

35. Burin, R.; Burin, V. M.; Taha, P.; Bordignon-Luiz, M. T.; Ciênc. Tecnol. Aliment. 2008, 28, 973.

36. Rebellato, A. P.; Pacheco, B. C.; Prado, J. P.; Pallone, J. A. L.; Food Res. Int. 2015, 77, 385.

37. Scheid, A. L.; Micronutrientes: Filosofias de Aplicação e Eficiência Agronômica; ANDA: São Paulo, Brasil, 1999.

38. Römheld, V.; Marschner, H.; Plant Physiol. 1986, 80, 175.

39. El Mehdawi, A. F.; Quinn, C. F.; Pilon-Smits, E. A. H.; Curr. Biol. 2011, 21, 1440.

40. Kabata-Pendias, A.; Pendias, H.; Trace Elements in Soils and plants, $3^{\text {rd }}$ ed.; CRC Press: Boca Raton, 2001.

41. D’Imperio, M.; Renna, M.; Cadinali, A.; Buttaro, D.; Serio, F.; Santamaria, P.; Food Chem. 2016, 213, 149.
42. Pandey, N.; Gupta, B.; Pathak, G. C.; Sci. Hortic. 2013, 164, 474.

43. Tjahjadi, C.; Lin, S.; Breene, W. M.; J. Food Sci. 1998, 53, 1438.

44. Harnly, J. M.; Pastor-Corrales, M. A.; Luthria, D. L.; J. Agric. Food Chem. 2009, 57, 8705.

45. Naozuka, J.; Oliveira, P. V.; J. Braz. Chem. Soc. 2012, 23, 156.

46. Garcia, R. M.; Arocena, R. V.; Laurena, A. C.; Tecson-Mendoza, E. M.; J. Agric. Food Chem. 2005, 53, 1734.

47. Moreno, F. J.; Jenkins, J. A.; Mellon, F. A.; Rigby, N. M.; Robertson, J. A.; Wellner, N.; Mills, E. N. C.; Biochim. Biophys. Acta, Proteins Proteomics 2004, 1698, 175.

48. Sun, S. S. M.; Leung, F. W.; Tomic, J. C.; J. Agric. Food Chem. 1987, 35, 232.

49. Garcia, J. S.; Magalhães, C. S.; Arruda, M. A. Z.; Talanta 2006, $69,1$.

50. Minekus, M.; Alminger, M.; Alvito, P.; Ballance, S.; Bohn, T.; Bourlieu, C.; Carrière, F.; Boutrou, R.; Corredig, M.; Dupont, D.; Dufour, C.; Egger, L.; Golding, M.; Karakaya, S.; Kirkhus, B.; Le Feunteun, S.; Lesmes, U.; Macierzanka, A.; Mackie, A. R.; McClements, D. J.; Ménard, O.; Recio, I.; Santos, C. N.; Singh, R. P.; Vegarud, G. E.; Wickham, M. S. J.; Weitschies, W.; Brodkorb A.; Food Funct. 2014, 5, 1113.

51. Leufroy, A.; Noël, L.; Beauchemin, D.; Guérin, T.; Anal. Bioanal. Chem. 2012, 402, 2849.

52. Ortega-Blu, R.; Molina-Roco, M.; Agrociencia 2007, 41, 491.

Submitted: October 24, 2016

Published online: February 17, 2017 